\title{
Development of Measuring Device for Non-Invasive Blood Sugar Levels Using Photodiode Sensor
}

\author{
Frendi Agung Dwi S, Bedjo Utomo, Sumber \\ Department of Electromedical Engineering Poltekkes Kemenkes, Surabaya \\ Pucang Jajar Timur No. 10, Surabaya, 60245, Indonesia \\ Email: Frendydwi.fd13@gmail.com
}

\begin{tabular}{ll}
\hline \multicolumn{1}{c}{ Article Info } & Abstract \\
\hline $\begin{array}{l}\text { Article History: } \\
\text { Receive Mei } 15,2020\end{array}$ & $\begin{array}{l}\text { Diabetes mellitus is one of the deadliest diseases faced by Indonesians. To measure blood sugar levels, } \\
\text { the most widely used tool is an invasive tool, namely by injuring the patient's body. Techniques like this } \\
\text { make people reluctant to measure glucose levels in their blood regularly. Therefore, this research aims } \\
\text { Revised August } 10,2020 \\
\text { Received August } 30,2020\end{array}$ \\
$\begin{array}{l}\text { to design and build a non-invasive blood sugar measuring device using a photodiode sensor. So that this } \\
\text { tool can be used by all groups, both medical and non-medical personnel to measure blood sugar non- } \\
\text { invasively. In this study, blood was drawn from several patients with Miletus diabetes and carried out } \\
\text { direct blood measurements using a photodiode sensor. The results obtained from this study are that } \\
\text { there is an error value in the voltage measurement circuit with the calculation of the resistance value to } \\
\text { obtain the voltage value. The error value obtained is 5\%, the linear regression value is } 0.996 . \text { From the } \\
\text { mon-Invasive }\end{array}$ & $\begin{array}{l}\text { measurement results, it can be concluded that the photodiode sensor can be used to measure blood sugar } \\
\text { non-invasively. }\end{array}$ \\
$\begin{array}{l}\text { Blood Sugar Level } \\
\text { Phega } 328\end{array}$ &
\end{tabular}

Photodiode

TFT LCD

\section{Corresponding Author: \\ bedjoutomo123@gmail.com \\ Department of Medical Electronics Engineering Technology}

This work is an open-access article and licensed under a Creative Commons Attribution-ShareAlike 4.0 International License (CC BY-SA 4.0).

\section{INTRODUCTION}

Diabetes is a chronic disorder associated with abnormal (emotional) blood sugar levels in the blood [1]. Diabetics in Indonesia for a certain period of time, during 2014-2015, Indonesia rose to 7 th place in the number of people with diabetes mellitus in the world. Diabetes with high blood sugar levels in the long term will cause chronic damage and dysfunction of various tissues, especially the eyes, kidneys, heart, blood vessels, and nerves [3]. To measure blood levels, the average user today is by using an invasive technique or by taking a blood sample from a patient and then using a tool. Sulistyani et al made a study on a non-invasive sugar assay [7]. However, in this study, the level of the tool is still weak because the error value is still high. Measurement of blood sugar levels also performed using a non-invasive method, a photodetector sensor is used with the beam of a NIR LED beam that passes through the radius [4]. However, this study has not used a portable system so that it cannot be used in everyday measurements. Zulkarnain et al. Laser Speckle Imaging (LSI) method was used to measure blood sugar levels [8]. However, in this study still using cameras, lasers, and computers in measuring blood sugar levels. Hariyanto et al, non-invasive measurement of blood sugar levels using the ATMega 8535 microcontroller [9] as a processing process to detect blood sugar levels. However, in this study still using a character LCD screen. In 2018 Duong created a design for a Non-Invasive Blood Glucose Measurement Module [10]. However, in this study, the measurement inaccuracy is still quite high. In 2012 Abdallah et al made a study on Multi-Sensor System Design for Non-Invasive Glucose Monitoring Using Optical Spectroscopy [11]. However, this research must use a microscope and a spectrometer to measure emissions. In 2015 Sairan et al conducted a study on the Design and Development of a Non-Invasive Blood Glucose Measurement System using the NIR (Near InfraRed) Technique [12]. However, in this study, the display used is still using the $16 \times 2$ character LCD. In 2019, Wilbert et al. Made a study of advances supported by both invasive and noninvasive [13]. However, in this study only compared the techniques, devices, and sensors used in previous studies. In 2017 Daarani et al made a study on Monitoring Blood 
Glucose Levels Using Noninvasive Methods with Near InfraRed Sensors [14]. However, in this study still using the character LCD as a display and must use Bluetooth that asks for approval on the cell phone. In 2011 Ashok et al made a study on Measurement of Blood Glucose Using Noninvasive Techniques [15]. However, in this study using a laser to measure blood sugar levels. In 2019, Betty et al made a study of non-invasive blood sugar using Near-Infrared spectroscopy [16]. However, in this study classifying patients must be connected by Bluetooth to be accessed on mobile phones. In 2015 Lawand et al conducted research on the Design and Development of Non-Invasive Blood Glucometers using Infrared LEDs [17]. But in this study still using computers in displaying the value of electoral. In 2018 Nuwan made a study on Non-Invasive Blood Glucose Monitoring using Hybrid Techniques [18]. But in this study, the error value in the measurement of sugar levels is still high. In 2016 Periyasami et al conducted a study on a study of the estimation of non-invasive blood acquisition using capacitance measurement techniques [19]. However, in this study, the capacitance value has not been approved on the LCD. In 2017 Shulei et al made a study of Non-invasive Blood Glucose Measurement Schemes Based on Near-infrared Spectroscopy [20]. However, in this study data must be collected on a computer to measure the blood glucose. In 2019 Haryono et al made a study on the Design of Blood Sugar Level Measuring Devices Using Non-Invasive Techniques Based on Arduino Uno Microcontroller [21]. But in that study, the display still used LCD characters.

Based on the identification of the problem, it is stated that a non-invasive blood sugar measuring device has been made, so the authors want to develop it by designing a non-invasive blood sugar measuring device using a photodiode sensor. This study aims to make it easier for users or nurses to check blood sugar without going through a syringe. The author plans to use the linearity graph method to produce a formula for calculating blood sugar. The tool made is expected to be used to determine the results of non-invasive blood sugar levels. Therefore this tool has a high level of practicality and is easier to use.

This article consists of Chapter 1 Introduction, Chapter 2 Materials and Methods, Chapter 3 Results, Chapter 4 Discussion, Chapter 5 Conclusions, and Chapter 6 References.

\section{MATERIALS AND METHODS}

\section{A. Experimental Setup}

This study used five subjects aged 21 and 22 years. Subjects were taken randomly and data collection was repeated 1 time. Blood sugar data is taken from measurements using an invasive blood sugar measurement device and then compared to measurements using this device.

\section{B. Materials and Device}

This study uses the LED $(5 \mathrm{~mm})$ as a light source. Photodiode (100K) to receive LED light that passes through a finger. Microcontroller Arduino (ATMEGA328) for data processing. TFT LCD for displaying values.

\section{Experiment}

In this study, using LED light for light sources then passes through the finger and is received by the photodiode. The principle is detecting the density of blood on the fingers. Then the photodiode produces resistance and is processed by voltage distribution. Analog data is converted to digital using a microcontroller and then reads the $\mathrm{ADC}$ value. $\mathrm{ADC}$ result data are processed and produce blood sugar values then compared to an invasive blood sugar check device.

\section{The Diagram Block}

When the power button is pressed, all circuits are powered by batteries, so that the entire circuit is ready for operation. The Photodiode sensor will detect the intensity of the LED light passing through the finger. The photodiode sensor detects the density of blood in the finger to obtain a resistance value which is then processed in a voltage distribution circuit. The output voltage distribution circuit goes to Arduino to be processed into digital data. Digital data processing uses a formula to obtain blood sugar values. Blood sugar data is then displayed on the TFT LCD. (Fig. 1).

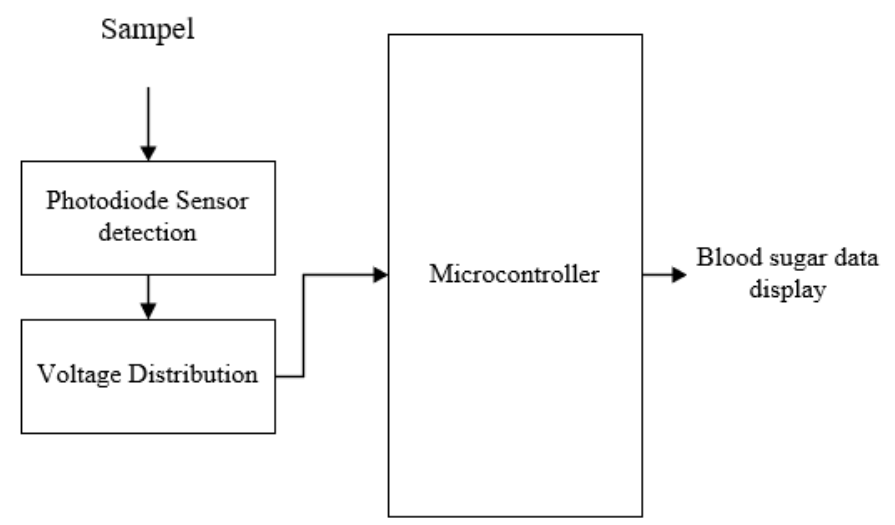

Fig. 1. The diagram block of Development of measuring devices for noninvasive blood sugar levels display on TFT

\section{E. The Flowchart}

The process begins when the photodiode circuit works to detect the voltage based on the LED light passing through the finger. Then press the start button to start reading the analog value of the photodiode circuit. Then the analog data is converted to digital data using a microcontroller. When the start button is not pressed, data reading has not yet occurred. Then the data is processed in a microcontroller and produces blood sugar levels produced from the ADC data. Data on blood sugar levels are displayed on the TFT screen. The reset button is used to return to the initial process. After the blood sugar value comes out, the process is complete (Fig. 2). 


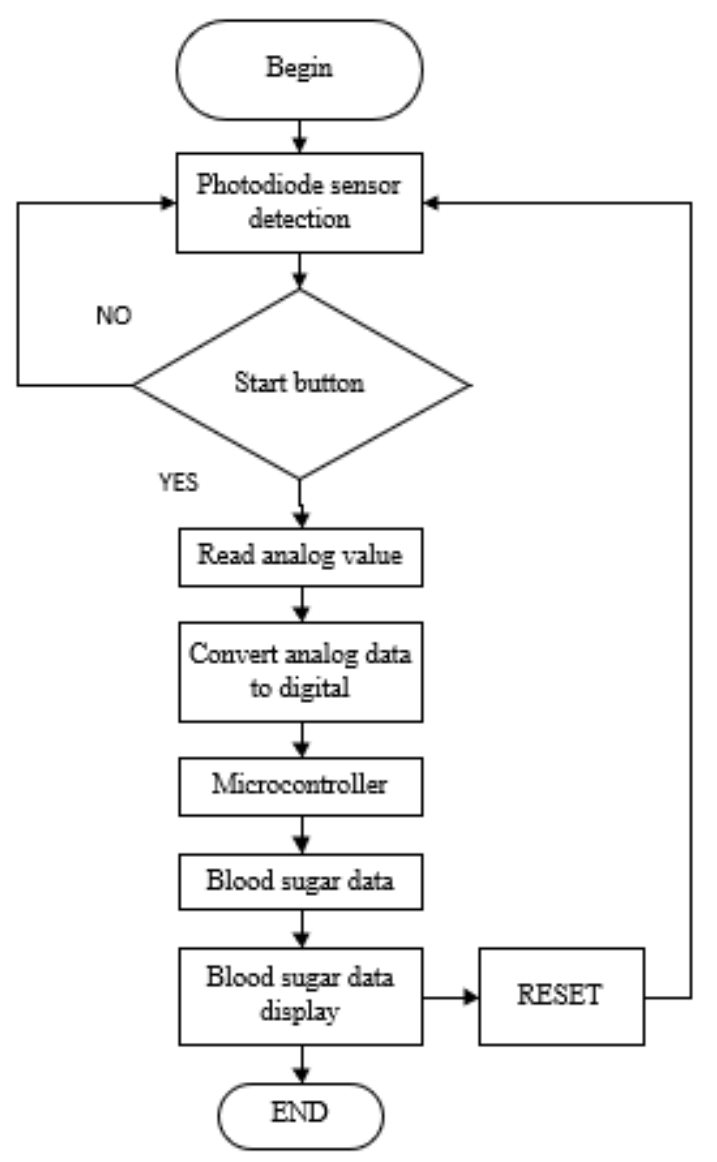

Fig. 2. The Flowchart of Development of measuring devices for non-invasive blood sugar levels display on TFT

\section{F. Circuit}

1) Circuit of microcontroller

In (Fig 3. ) Overall module performance can be categorized as good. LED circuit performance, photodiode, and voltage distribution are good. To obtain a linear regression value requires a series of LEDs, photodiode, voltage distribution, and Arduino. There is a problem when collecting blood sugar data because there is an outbreak of covid19 for collecting blood sugar respondent data cannot be done.

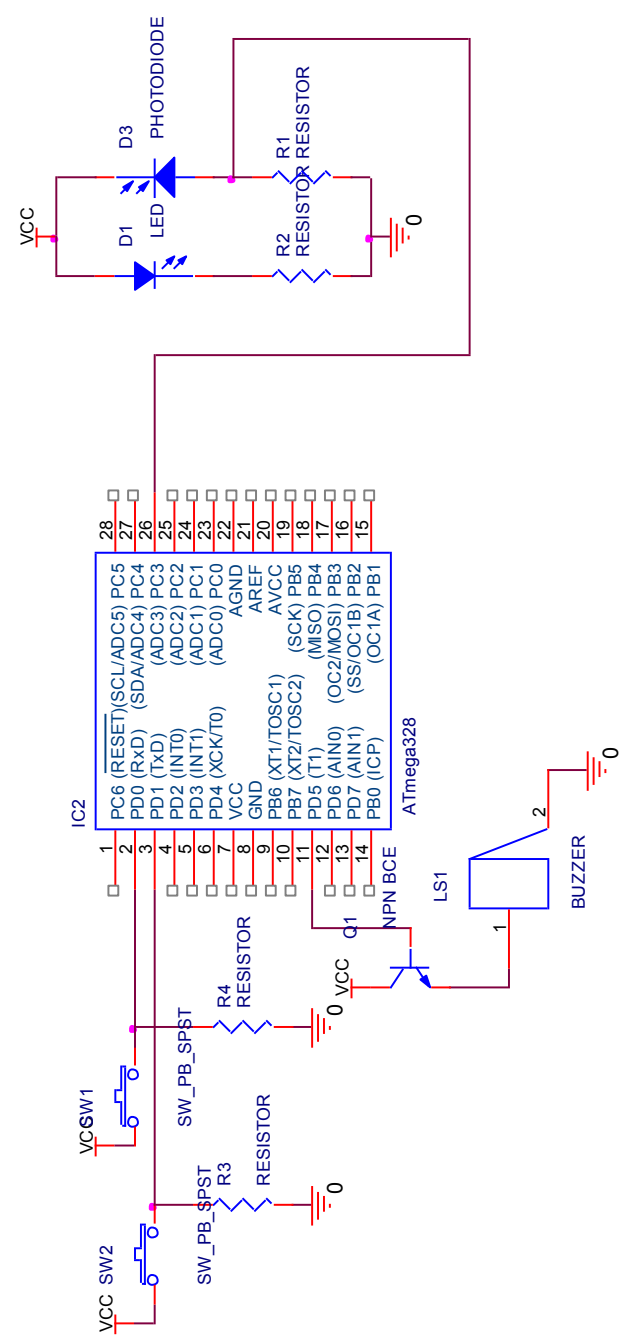

Fig. 3. Circuit of microcontroller

III. RESUlts

A. Results of microcontroller circuit design

In (Fig 4.) is a tool box and some supporting components. On the outside of the box is a TFT LCD then there is a start and reset button. The circuit is supplied with a $5 \mathrm{~V}$ battery and data is processed on an Arduino Microcontroller. Arduino boards and LED Photodioda circuits are inside the box. 


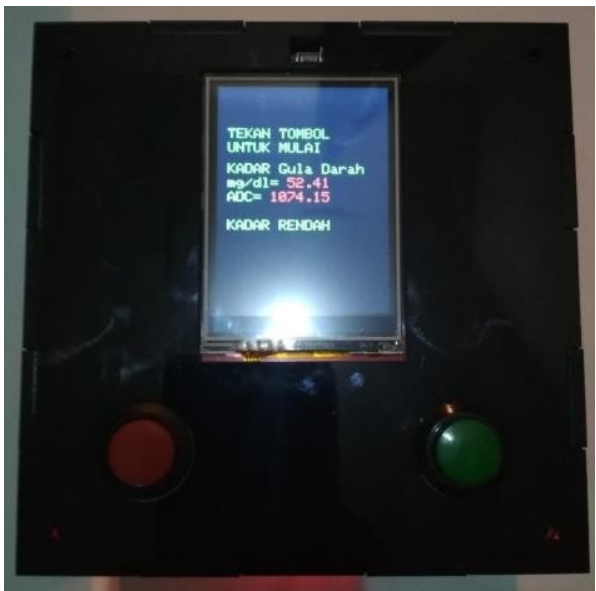

Fig. 4. Results of microcontroller circuit design

\section{B. Listing program for Library and Initialization}

The program below functions for initial initialization and use of libraries in it. There is a TFT LCD library and several variable initializations used in data processing.

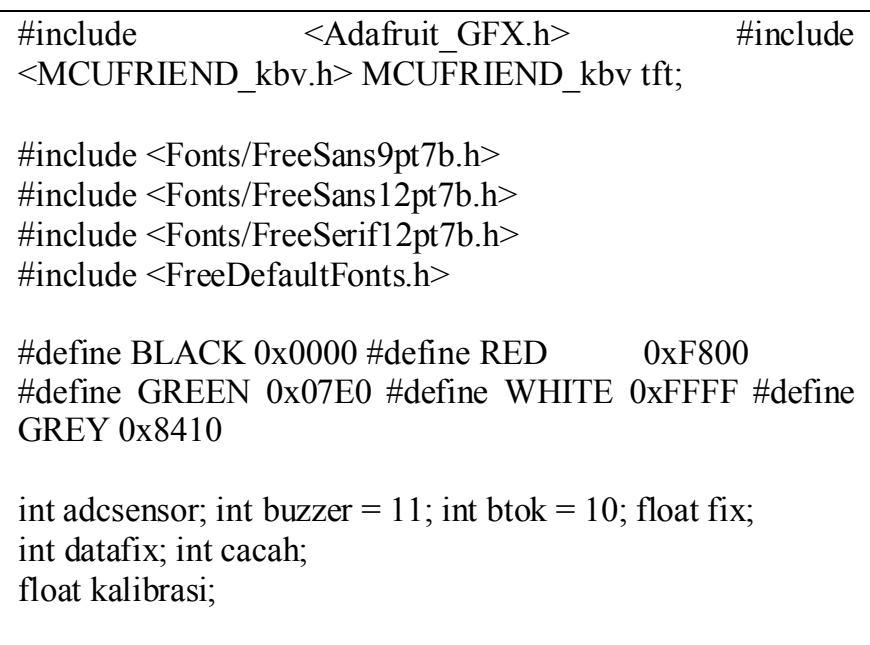

\section{Listing Program for Void Setup}

The program below is a void setup program that functions to run the initial logic on this program. The initial logic or initial program that is run is the logic for setting the TFT LCD and the buzzer condition when the module is powered on.

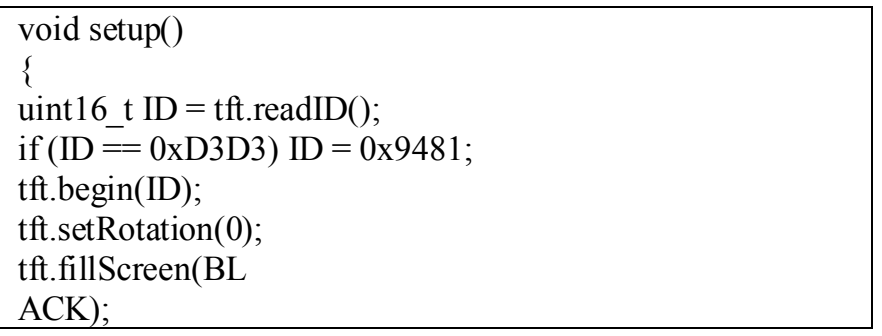

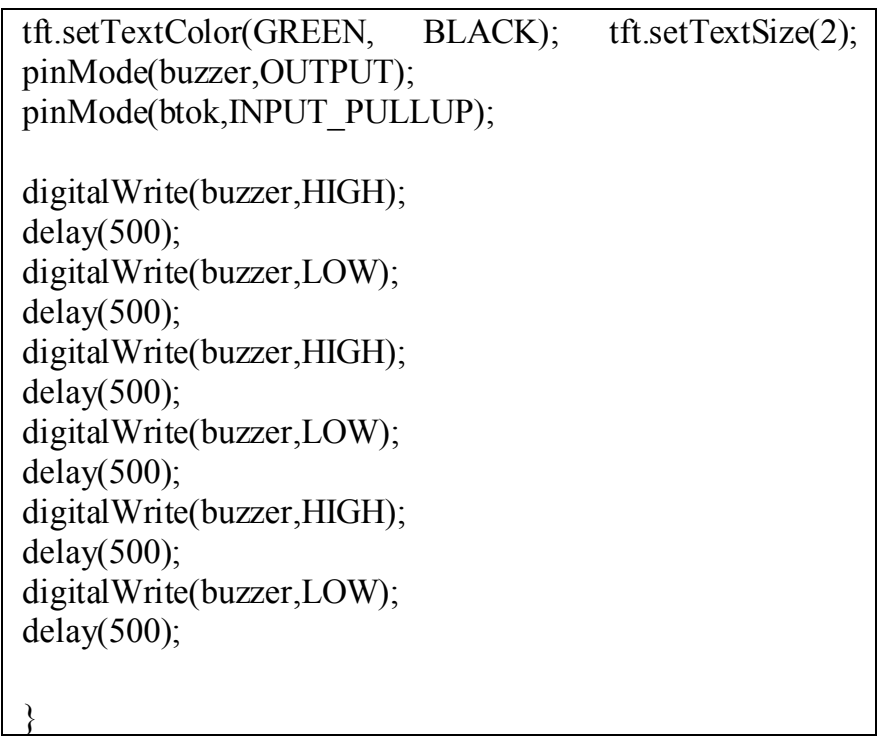

\section{Listing program for Void Loop}

The program below is a void loop function that is used to run logic continuously. In the void loop program, there is logic to call other voids, the process voids. Then the results of the process voids are displayed on the TFT LCD.

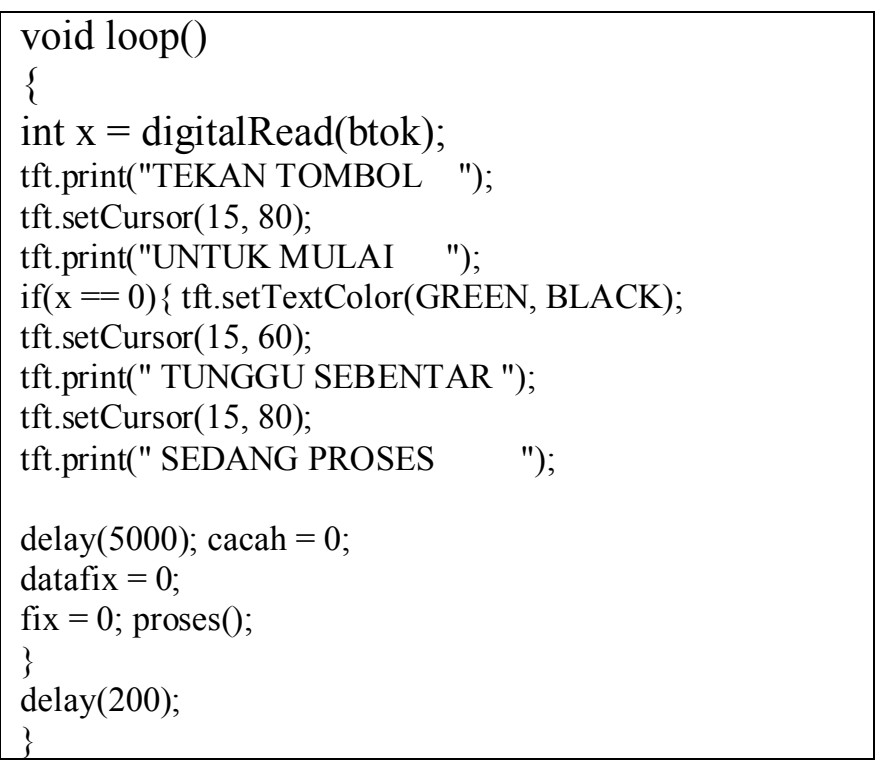

\section{E. Listing Program for Void Proses}

The program below is a process void whose function is to receive ADC data from Arduino A3 pins and then it is processed using coefficient values that have been obtained from the linearity regression values.

void proses()\{

adcsensor $=$ analogRead(A3); 
tft.setTextColor(GREEN, BLACK); tft.setCursor(15, 60); tft.print("Monitor Gula Darah "); tft.setCursor(15, 80); tft.print("ADC= "); tft.setTextColor(RED, BLACK);

tft.print(adcsensor); tft.print(" ");

cacah++;

datafix $=$ adcsensor + datafix; delay $(10)$;

if $($ cacah $>20)\{$

fix $=$ datafix / 20.0;

kalibrasi $=($ fix -1022.1$) / 0,996$;

\section{F. Linearity graph}

In (TABLE I. \& Fig 5.) is the result of the measurement module of the blood sugar measurement device EasyTouch Glucometer. The results of measurements on 5 respondents were used to determine the regression value resulting from the linearity graph.

TABLE I. THE MEASUREMENT RESULTS OF THE VOLTAGE DISTRIBUTION CIRCUIT WITH A STANDARD DEVICE

\begin{tabular}{ccc}
\hline Respondent & $\begin{array}{l}\text { Measuring } \\
\text { Instrument }\end{array}$ & ADC \\
\hline 1 & 55 & 927 \\
\hline 2 & 67 & 928 \\
\hline 3 & 76 & 929 \\
\hline 4 & 88 & 930 \\
\hline 5 & 96 & 931 \\
\hline
\end{tabular}

\section{Linearity Graph}

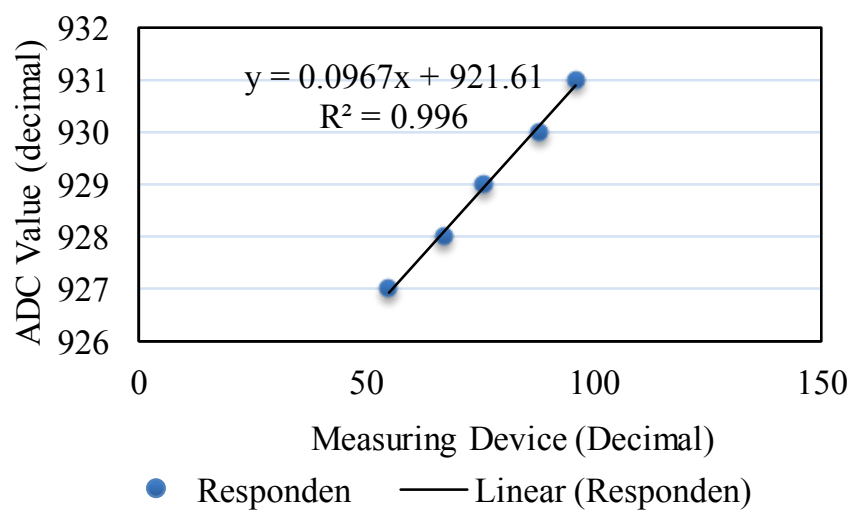

Fig 1. Linearity Graph

\section{G. Module Testing of Respondents}

In (TABLE II.) is the result of testing the LED circuit, photodiode, and voltage distribution on the module. Data taken from 5 respondents showed varying results of photodiode resistance. Voltage measurements in the circuit shown varied data and there is a difference with the calculation. The calculation used is the formula for the distribution of voltage with the value of the photodiode resistance obtained from previous measurements and a ground resistor value of $100 \mathrm{~K}$.

TABLE II. THE MEASUREMENT RESULTS OF THE VOLTAGE DISTRIBUTION CIRCUIT ON THE RESPONDENT

\begin{tabular}{cccc}
\hline Respondent & $\begin{array}{c}\text { Resistance } \\
(\mathrm{K} \Omega)\end{array}$ & $\begin{array}{c}\text { ADC } \\
(\mathrm{V})\end{array}$ & $\begin{array}{c}\text { Calculation } \\
(\mathrm{V})\end{array}$ \\
\hline 1 & 61.4 & 3.3 & 3.09 \\
\hline 2 & 52.6 & 3.4 & 3.27 \\
\hline 3 & 52.1 & 3.4 & 3.27 \\
\hline 4 & 47.2 & 3.5 & 3.39 \\
\hline 5 & 59.6 & 3.3 & 3.13 \\
\hline
\end{tabular}

\section{DisCUSSION}

In this study, (Table 1) shows data on ADC values and blood sugar values using invasive. The second result of the data is then searched for regression values to be used as a formula for calculating blood sugar. The data is processed by the linearity formula using Microsoft Excel and then a regression value of 0.998 is obtained. The value is then used for reference every time an $\mathrm{ADC}$ value is entered.

(Table 2) shows the results of measurements on the voltage distribution circuit. In the table, there is the value of the photodiode resistance, the voltage measurement results of the voltage distribution circuit, and the calculation of the voltage value using the photodiode resistance. This data produces a difference between measurements with the calculation of the value of the voltage in the voltage distribution circuit. The difference results are then calculated the error value and produce an error value of $5 \%$.

In a study [2] discusses the manufacture of measuring devices for non-invasive blood sugar levels using spectroscopy techniques, but in this study can not display the value on the LCD. In a study [11] discusses the manufacture of measuring devices for non-invasive blood sugar levels, but the research requires a lot of costs

\section{CONCLUSION}

The results that have been obtained from this study are that there is an error value in the measurement of the voltage distribution circuit with the calculation of the resistance value to get the voltage value. The error value obtained is $5 \%$. The results of the linear regression value of 0.996 . For further research, researchers are expected to be able to find other equations to calculate the value of non-invasive blood sugar and find references about the series used in non-invasive measurements.

\section{REFERENCES}

[1] B. Irfanudin, R. Patmasari, and H. Fauzi, "Perancangan Dan Implementasi Alat Pengukur Kadar Glukosa Dalam Darah Secara Non-Invasive Berbasis Arduino," eProceeding Eng., vol. 3, no. 3, pp. 4665-4668, 2016. 
[2] M. S. Asekar, "Glucose Measuring Device Using NIR Spectroscopy," 2018 Second Int. Conf. Intell. Comput. Control Syst., no. Iciccs, pp. 572$575,2018$.

[3] W. Po, "W PO o o," no. 12, 2013.

[4] M. S. Arefin, A. H. Khan, and R. Islam, "Non-invasive blood glucose determination using near infrared LED in diffused reflectance method," ICECE 2018 - 10th Int. Conf. Electr. Comput. Eng., pp. 93-96, 2018.

[5] N. D. Nanayakkara, S. C. Munasingha, and G. P. Ruwanpathirana, "Noninvasive blood glucose monitoring using a hybrid technique," MERCon 2018 - 4th Int. Multidiscip. Moratuwa Eng. Res. Conf., pp. 7-12, 2018.

[6] Subiyono, M. A. Martsiningsih, and D. Gabrela, "Gambaran Kadar Glukosa Darah Metode GOD-PAP (Glucose Oxsidase - Peroxidase Aminoantypirin) Sampel Serum dan Plasma EDTA (Ethylen Diamin Terta Acetat)," J. Teknol. Lab., vol. 5, no. 1, pp. 5-8, 2016.

[7] A. Uji, K. Gula, and D. Darah, "Seminar Tugas Akhir Juni 2017 Seminar Tugas Akhir Juni 2017 Dibuatnya alat ukur kadar gula dalam darah secara non-invasive.," pp. 1-8, 2017.

[8] K. G. Darah, "Investigasi Penggunaan Metode Laser Speckle Imaging (LSI) untuk Pengukuran Kadar Gula Darah," J. Fis., vol. 8, no. 2, pp. 6067, 2018.

[9] J. Sains, E. Hidayanto, H. Sutanto, and Z. Arifin, "Design of Non-Invasive Glucometer Using Microcontroller Atmega-8535," J. Sains Dan Mat., vol. 23, no. 3, pp. 78-83-83, 2015.

[10] D. T. Luong, N. X. Huy, D. V. Hung, N. T. Ha, and N. D. Thuan, "Research and Design a Non- Invasive Blood Glucose Measuring Module," Am. J. Biomed. Sci., vol. 10, no. 3, pp. 149-156, 2018.

[11] H. W. and T. H. O. Abdallah, A. Bolz, J. Hansmann, "Design of a Compact Multi-Sensor System for Non-Invasive Glucose Monitoring Using Optical Spectroscopy," Int. Conf. Electron. Biomed. Eng. its Appl., 2012.

[12] K. Sairam, A. Govada, C. H. Renumadhavi, B. S. Satyanarayana, and K. B. Ramesh, "Design and Development of Non-Invasive Blood Glucose Measurement System using Near Infrared technique," Ijarcsse, vol. 4, no. 7, pp. 74-79, 2015.

[13] W. V. Gonzales, A. T. Mobashsher, and A. Abbosh, The progress of glucose monitoring - A review of invasive to minimally and non-invasive techniques, devices and sensors, vol. 19, no. 4. 2019.

[14] I. Journal and L. Trends, "Blood glucose level monitoring by noninvasive method using near infra red sensor," Int. J. Latest Trends Eng. Technol., vol. IRES, no. 1, pp. 141-147, 2017.

[15] V. Ashok, A. Nirmalkumar, and N. Jeyashanthi, "A novel method for blood glucose measurement by noninvasive technique using laser," World Acad. Sci. Eng. Technol., vol. 51, no. 3, pp. 676-682, 2011.

[16] B. E. Manurung, H. R. Munggaran, G. F. Ramadhan, and A. P. Koesoema, "Non-invasive blood glucose monitoring using near-infrared spectroscopy based on internet of things using machine learning," IEEE Reg. 10 Humanit. Technol. Conf. R10-HTC, vol. 2019-Novem, pp. 5-11, 2019.

[17] K. Lawand, M. Parihar, and S. N. Patil, "Design and development of infrared LED based non invasive blood glucometer," 12 th IEEE Int. Conf. Electron. Energy, Environ. Commun. Comput. Control (E3-C3), INDICON 2015, pp. 1-6, 2016.

[18] N. D. Nanayakkara, S. C. Munasingha, and G. P. Ruwanpathirana, "Noninvasive blood glucose monitoring using a hybrid technique," MERCon 2018 - 4th Int. Multidiscip. Moratuwa Eng. Res. Conf., pp. 7-12, 2018.

[19] R. Periyasamy and S. Anand, "A study on non-invasive blood glucose estimation - An approach using capacitance measurement technique," Int. Conf. Signal Process. Commun. Power Embed. Syst. SCOPES 2016 Proc., pp. 847-850, 2017.

[20] W. Shulei, Y. Xueguang, and Z. Yangan, "Non-invasive blood glucose measurement scheme based on near-infrared spectroscopy," Opt. InfoBase Conf. Pap., vol. Part F122-, pp. 2-5, 2017.

[21] H. Suyono, "Perancangan Alat Pengukur Kadar Gula dalam Darah Menggunakan Teknik Non-Invasive Berbasis Mikrokontroler Arduino Uno," vol. 06, no. 01, pp. 69-76, 2020. 